\title{
Neopatrimonial Model of Public Administration and its Transformation in the Context of Global Uncertainty
}

\author{
Viacheslav Maracha ${ }^{1,2 *}$, Sergey Bespalov ${ }^{1}$ \\ ${ }^{1}$ Russian Presidential Academy of National Economy and Public Administration (RANEPA), RU-119571, Moscow, Russian Federation \\ ${ }^{2}$ Financial University under the Government of the Russian Federation, Department of System Analysis in Economics, RU-125993 \\ Moscow, Russian Federation
}

\begin{abstract}
The coordinate system for describing practices of public administration in developed countries is set by three basic models: rational bureaucracy, New Public Management, and New Governance, which are "layered" on top of each other. However, in many developing countries, these models work differently, and instead of an upward movement, a spiral of reforms and counter-reforms is obtained. Moreover, in the face of global uncertainty generated by the transformation of the world order and the intensified COVID-19 pandemic, it is even more difficult to borrow the best practices from highly developed countries. The institutional model of neopatrimonialism, which includes the informal core and the formal periphery of the system of state institutions, has serious potential for understanding the specifics of government in developing countries. The value-neutral interpretation of neopatrimonialism opens up a broader view of such problems as state interventions into the economy, the relationship between power and property, the national model of democracy, etc. For Russia, the authors propose the redistributive neopatrimonialism model. Neopatrimonialism appears to be a phase in the cycle "mobilization system - stagnation neopatrimonialism - renewed mobilization system". It is hypothesized that the next phase will be built taking into account the principles of open network organization and solidarity.
\end{abstract}

\section{Introduction}

The coordinate system for describing the transformation of public administration models in developed countries is set by three main public administration models: the classical Weberian model of "rational bureaucracy", project-target model "the New Public Management" (NPM) and social-network model "the New Governance" [1]. However, attempts to apply these approaches to describe the processes in many countries of "catching up" development, all the more to put them in the basis of transformations of the state apparatus, often lead to very specific results: models in these cases work in a completely different way, and instead of an upward movement, as it were "layering" models on top of each other, we get a spiral of reforms and counterreforms. Moreover, in the face of global uncertainty generated by the transformation of the world order and the intensified COVID-19 pandemic, the best practices of developed countries no longer seem so immutable.

In this situation, the institutional model of neopatrimonialism possesses a serious potential both for the interpretation of the attempts at transformations that have already taken place and for the design of reforms in public administration [2]. This is especially true for the aspects of reforms related to the adaptation of their institutional design to existing informal institutions, forecasting the consequences of reforms and reducing the risks of counter-reforms.

The institutional model of neopatrimonialism includes the informal core and formal periphery of the system of public institutions. In classical "normative" institutions, the situation is reversed: the core is formal, while the periphery is informal. The research hypothesis, based on the proposed balanced model of institutions, is that the balance of formal and informal components of public administration institutions (or "skew" in one direction or another) is largely determined by the context of the wider systems: the sphere of public life, which includes a given institution, and the institutional order in general. In particular, the authors question the valueladen interpretation of neopatrimonialism, which identifies the latter with "unworthy governance", which must be overcome as soon as possible [3].

The value-neutral interpretation of neopatrimonialism as a control loop within the framework of statehood opens up a broader view of such problems as the role of the state in the economy, the ratio of power and property, the national model of democracy, allowing to adequately highlight and reasonably use the successful experience of the BRICS countries and some APR countries (Japan, South Korea, Singapore, Malaysia, etc.). At the same time, a clear understanding of the system stability mechanism allows predicting the factors of its instability and reducing the risks of

Corresponding author: maratcha@yandex.ru 
imbalance. In connection with the above, the problem of measuring the influence of informal relations on the decision-making processes of state bodies ("the level of neopatrimonialism”) becomes urgent.

A significant part of the paper is devoted to the specifics of the Russian model of public administration, which we define as "redistributive neopatrimonialism". To construct the model, we used the theory of institutional matrices by S. Kirdina-Chandler [4] and the distinction between the coordination structures of the "market” and "razdatok" proposed by O. Bessonova [5], which is interpreted from the organization theory point of view (the difference between "vertical" hierarchical, "horizontal" market and "mixed" network structures) [6]. Based on Bessonova's idea about the cyclical nature of Russia's institutional dynamics, the authors propose a hypothesis that redistributive neopatrimonialism is a transitional phase in the cycle "mobilization system stagnation - neopatrimonialism - renewed mobilization system", and the next phase will be based on the principles of open network organization and solidarity.

\section{Global trend in public administration development and peculiarities of Russian practice}

As shown in our previous works, the current global trend in public administration is the transition to the third generation of public administration practices (Public Administration 3.0), based on the idea of a "viable" state, combining the qualities of "strong", "effective" and "inclusive" [1]. As noted in the Introduction, these qualities of the state correspond to three basic ideal models of public administration from the practice of developed countries: "rational bureaucracy", NPM and New Governance, combined in "multimodal" public administration. Public Administration 3.0 is built on the principle of multimodality, the essence of which is that the tools of different models are used depending on the nature of the tasks being solved and are combined to solve complex problems for which the tools of any one model are not enough (figure 1 ).

These changes in the practice of public administration are taking place against the background of larger-scale processes that are engulfing public institutions and institutional governance.

The first large-scale process is the "networkization" of the economy and society, which is expressed in the following package of systemic changes [7]:

1) the economy and society are being transformed on the basis of network interaction with the dominance of horizontal ties;

2) governance systems and institutions based on the domination of hierarchical relations are gradually becoming uncompetitive, and they are being replaced by completely new ways of organization and selforganization: in the field of entrepreneurship, innovative clusters and ecosystems are formed, a "sharing" type of economy appears;

3) the change in the governance paradigm introduced by the network organization also affects the social sphere, public areas, interaction between the authorities and citizens; at the same time, network communities become new actors in the social space - they change the prevailing socio-economic practices, set requirements for infrastructure and urban environment, for the subject orientation and "targeting" of city and regional programs;

4) network interaction becomes a condition for the formation of collaborations and innovative environments in all of the above-mentioned areas - "living institutions" appear that can stimulate the growth of competitiveness in various areas of socio-economic development;

5) the state becomes open and "inclusive", increasing flexibility and developing a culture of interaction with public institutions, boosting the degree of their involvement and public participation in governance.

The second large-scale process is digitalization. In view of the fact that digitalization permeates all spheres of social life, while intensively interacting and intertwining with "networkization" in a complex way, we are talking about the process of "digital transformation" of the world (i.e. the economy, state and other spheres of society), which is expressed in the following social and institutional changes:

1) the state is turning into a public platform for the provision of high-tech services to citizens and entrepreneurs, as well as for the interaction of stakeholders in the name of public interests;

2) the proliferation of network connections and relationships is greatly simplified, which facilitates overcoming inter-level and inter-departmental barriers in state and municipal administration;

3) new channels and opportunities are opening up for horizontal interaction between the state authorities and stakeholders, including for creation communication platforms and transition to a partnership communication model.

The above changes make public administration transform into Public Administration 3.0, intensively developing the tools of all three basic models from the practice of developed countries and using them "multimodally". The latter means an integrated approach, in which a complex problem is divided by systems analysis into simpler ones, while the latter are solved using the most appropriate tools from different models. But this requires a higher level of coordination, since the use of tools from different models is based on the involvement of various competencies, which are either concentrated in specialized government bodies, departments or agencies, or a project team should be created for solving a complex problem, including specialists with the necessary competencies. In this case, the processes of solving simple problems, into which the original complex problem is "decomposed", must be coordinated in such a way that at a certain moment "gather" into a common result without loss of quality. This is exactly what digitalization and "networkization" should contribute to. 


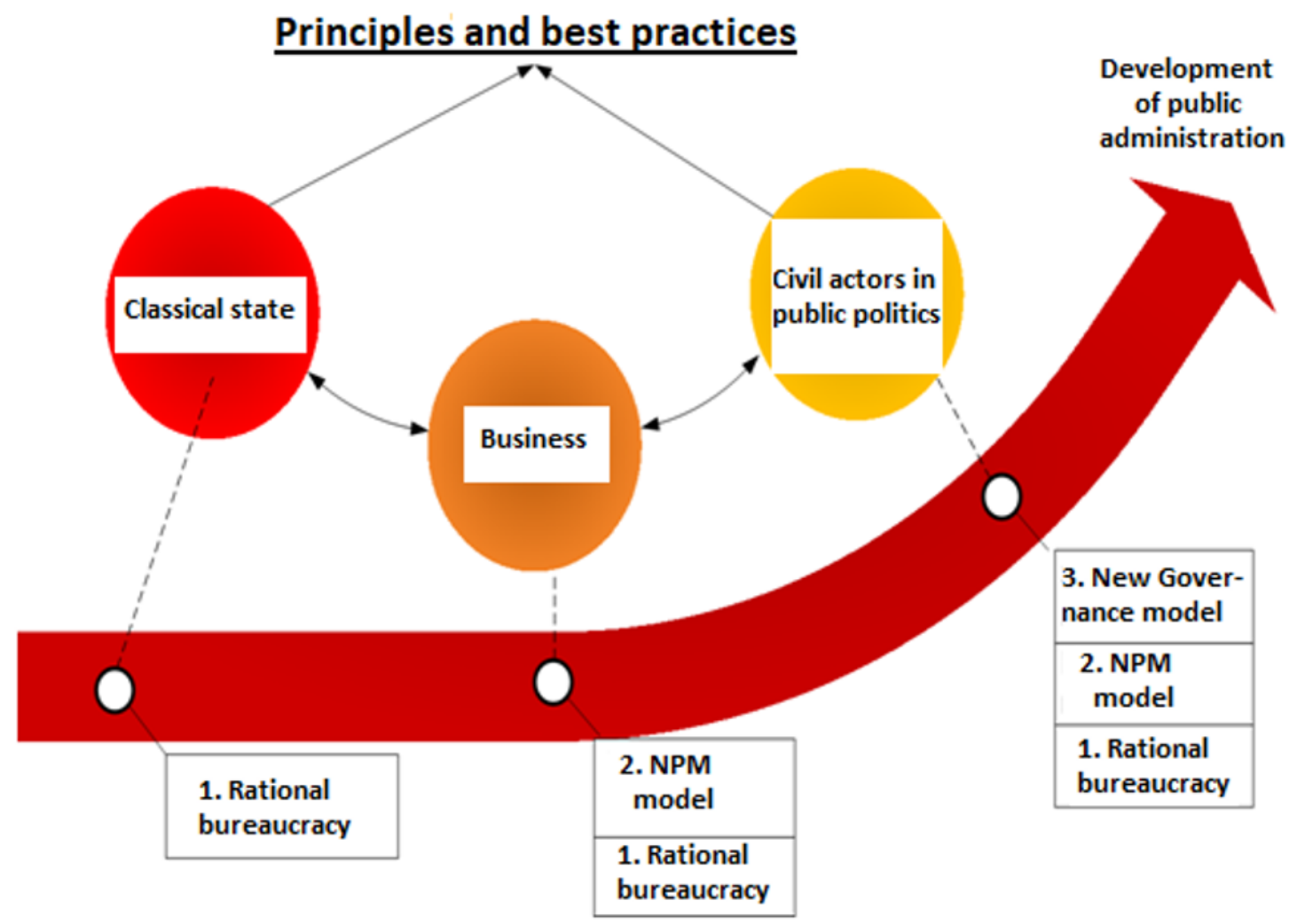

Fig. 1. The ratio of three ideal models of public administration from the practice of developed countries.

What is really happening in the practices of applying public administration basic models in Russia, if we compare them with the best practices of developed and even some successfully developing countries? We have already written about this in our previous works [1; 7], therefore, we restrict ourselves to a concise presentation of the diagnostic results.

1. In Russia, the three basic models work in a completely different way than in developed countries, and instead of an upward movement, "layering" the models on top of each other (Figure 1), we get a "spiral" of reforms and counter-reforms. Moreover, in the face of global uncertainty generated by the transformation of the world order and the intensified COVID-19 pandemic, the best practices of developed countries no longer seem so immutable.

2. The use of the tools of the classical model is burdened by the historical incompleteness of the processes of the modern "rational bureaucracy" formation.

3. The introduction of new models of public administration is taking place in the conditions of unsolved problems of the previous historical stage: the Russian bureaucracy is burdened with "post-Soviet" problems and is struck by the "traditionalism" of informal ties, which is typical for the majority of developing countries, and personal and clan patronage at the lower and middle levels of the government apparatus [8].

4. The use of tools of the New Governance model is associated with political restrictions: •communication with the population and other stakeholders often has a formal and imitative nature, while the state tries to limit itself to “convenient” dialogue partners, and sometimes even creates them artificially;

-strategic documents and decisions, if they are submitted for public discussion, then usually at the final stage of their development, when it is already difficult to change anything in them (substitution of the discussion on the essence by "popular approval”).

5. The market-oriented NPM model is being introduced with the following peculiarities ("three substitutions"):

-substitution of posing problems with "PR", striving for "varnishing reality";

-substitution of meaningful goal setting with the definition of target indicators;

•lack of independent feedback channels, substitution of meaningful analytics with infographics.

6. Project and program-target management is used not so much to achieve the stated goals, but to "slicing" budgets. Development and focus on the priorities for which these methods were created are not provided.

7. Attracting specialists with high industry specialization and unique competencies to the civil service is limited by insufficient motivation. Loyalty is valued, and the meritocratic system is not built.

8. The dominance of the "technocratic" approach to digitalization, while underestimating the role of the human factor and low motivation (point 6) against the background of the problems described in points 1-5, 
leads to the conservation of outdated public administration institutions: the "digitization" of ineffective procedures only complicates their improvement.

\section{The concept of neopatrimonialism as an attempt to explain "hybrid" forms of government. Measuring neopatrimonialism}

The concept of patrimonialism goes back to the theoretical constructions by $\mathrm{M}$. Weber, who viewed it as a method of domination based on the appropriation of public power (both political and economic) for private purposes; in other words, governing the state as a patrimonium - private property [9]. Neopatrimonialism is usually understood as the implementation of such a form of rule (essentially traditional) in modern conditions, and after Weber, this is opposed to rational (legal) domination. It is important to emphasize that the category of neopatrimonialism cannot be reduced only to the nature of the political regime, since, according to $\mathrm{N}$. Robinson [10], V. Gel'man [11] and others, it also covers the mechanisms of governance - political and economic ruling of the state. In systems of the neopatrimonial type, the ratio of the formal and informal components of institutions, hierarchies, and networks, as well as closed and open networks, is extremely significant. Neopatrimonialism can be considered as one of the variants of the limited-access order in the terminology of D. North and his co-authors [12].

The concept of neopatrimonialism arises as a response of specialists in developing countries to classical ideas about public administration within the framework of the general Weberian paradigm of patrimonial and rational bureaucracy analysis. Instead of the dominance of a rational bureaucracy, which Max Weber feared might swallow up market and political decision-making centers around the world, during the twentieth century in most developing countries, after a series of anti-colonial revolutions, peculiar hybrid forms of administration developed. In the early 1970s, S. Eisenstadt proposed one of the first interpretations that distinguish traditional patrimonialism and modern neopatrimonialism [2]. The further intellectual trajectory of the neopatrimonialism concept is associated with the comprehension of this stable alternative to a rational bureaucracy and state institutions in Africa, Latin America, Asia, and other regions [13]. Another important characteristic of the bureaucracy in developing countries is the significant diversity and coexistence of fundamentally different models and mechanisms of administration within the public administration system. A significant part of government bodies can be quite close to Weber's model of rational bureaucracy, interspersed with New Public Management and participatory institutions from the New Governance model, but regional administrations and part of central authorities can be more adequately described in terms of neopatrimonialism.
In this work, we rely on the conceptualization of G. Erdmann and U. Engel [14], which allowed us to synthesize the key approaches of predecessors and at the same time offer a clear differentiating definition of this phenomenon and concept in comparison with other related terms: patrimonialism, clientelism, patronage, patron-client relationships. In general, the most important thing for understanding the specifics of neopatrimonialism seems to be precisely the mixture of formal and rational mechanisms, on the one hand, and interpersonal, patron-client or informal, on the other hand. At the same time, formal legal institutions perform not only their usual functions but acquire secondary hidden functions. Common neopatrimonial practices imply both a fairly widespread possibility of strict adherence to specific rules or powers and a significant amount of arbitrariness or discretion, suggesting the possibility of informal transactions and decisions. In this perspective, neopatrimonialism is associated with the peculiarities of personnel selection and promotion, the payment system, the relationship of employees with external political and economic stakeholders, cultural norms, the quality and style of regulations, rules, and legislative acts, as well as law enforcement.

This structural uncertainty allows actors within the system to engage in complex negotiations or bargaining over whether a formal order will be applied in a particular case or an informal solution can be found. At the same time, the possibility of applying sanctions for non-compliance with formal procedures remains, so that the rule is not only fictitious but also has additional significance. Sanctions for its violation become a control mechanism within the administrative hierarchy, in which violations are quite common. Rational bureaucracy and its subsequent improved versions (NPM and the participation model or New Governance) are generally more effective, neopatrimonial mechanisms are also effective in certain situations. The application of this concept to understanding the models of administration in Russia is due to the idea of their mosaic nature.

So for transition countries it becomes relevant the problem of measuring the influence of informal relations on the decision-making processes performing by government bodies ("the level of neopatrimonialism"). For example, Rachel Sigman and Staffan Lindberg from the Varieties of Democracy Institute (V-Dem https://www.v-dem.net/en) use empirical tools to assess the levels of neopatrimonialism in African political regimes [15]. Further we consider the general method of measuring neopatrimonialism.

$\mathrm{V}$-Dem project is one of the largest-ever social science research-oriented data collection programs which co-ordinates the network of almost 3000 country experts. The V-Dem indicators (approximately 350 in total) are based on assessments by experts who are situated both within and outside each country. The latest version of the dataset, V10, covers 202 countries from 1789-2019 with annual updates to follow. It is co-hosted by the University of Gothenburg and University of Notre Dame. The V-Dem dataset includes measures of both de jure and de facto aspects of political regimes [16]. Neopatrimonialism includes elements of patrimonial 
(mostly informal) and rational-bureaucratic rule which co-exist and are sometimes interwoven. It implies de facto practices guided by norms or informal rules that differ from those typically associated with the corresponding formal institutions, so the large selection of de facto indicators is very helpful for measuring neopatrimonialism.

For conceptualising neopatrimonialism Sigman and Lindberg apply the model by Bratton and Van de Walle [17] who define a neopatrimonial regime as one that includes clientelism, presidentialism and the use of public resources for private/political benefit (a particular case of the third is corruption). Following this conceptual model, Sigman and Lindberg use indicators from the V-Dem dataset to construct an index of neopatrimonial rule. In addition to an overall index measuring the latent concept of neopatrimonial rule predicted by indicators across these three dimensions, they also produce sub-indices for each of the three dimensions. The sub-indices permit finer-grained analysis to better understand patterns of variation across the three dimensions and how the different dimensions relate to one another. Each of the four indices are derived using a Bayesian factor analysis (BFA) [18] which allows to estimate the latent concepts from the means of the posterior distributions of each of the $\mathrm{V}$ Dem indicators included in each dimension. The overall Neopatrimonialism index uses the BFA technique on the pool of 16 indicators employed in the three sub-indices [16].

These measurements show that the degree of neopatrimonialism in African countries varies vastly within the continent. There is a clear visible difference between countries scoring lowest and highest on the Neopatrimonialism index. The dimensions of neopatrimonialism are also configured variously. For instance, "clientelistic" regimes tend to also score high on corruption, although there are some exceptions, where moderate levels of political patronage are combined with high corruption. Furthermore, less "presidentialistic" regimes vary considerably in the extent to which their politics are "clientelistic" and plagued by corruption.

Sigman and Lindberg adapted the conceptual model of neopatrimonialism by Bratton and Van de Walle for the particular conditions and development context of African countries. We can made a plausible assumption that other groups of countries (Latin American, East Asian, Arab, Post-Soviet, East European, etc.) will require other conceptual models with different dimensions of the Neopatrimonialism index that will be projected otherwise onto the V-Dem dataset. Analysis of Sigman and Lindberg's work allows us to define the generalised method for constructing Neopatrimonialism index, consisting of the following four steps [19]:

1) based on conceptual considerations, a model is constructed with a few key indicators corresponding to the essential characteristics ("dimensions") of the concept;

2) indicators corresponding to these "dimensions" are disaggregated into a larger number of sub-indices that have a specific empirical relationship within the V-Dem dataset or some other commensurate database;

3) the secondary analysis of the data is carried out using suitable mathematical methods, which makes it possible to statistically verify the empirical consistency of the conceptual model;

4) if the consistency of the conceptual model is verified, then we can use its key indicators to measure (quantify) the essential characteristics of neopatrimonialism in the corresponding group of countries.

\section{Redistributive neopatrimonialism as an institutional model of public administration: key characteristics}

The diagnosis of the public administration peculiarities in Russia presented in the 2nd part of this paper allows us to propose the following research hypothesis (in three theses):

1. With regard to the conditions of Russia, we can talk about a specific kind of neopatrimonial model redistributive neopatrimonialism, which:

-includes the interacting informal core and the formal periphery of the public administration system - i.e. corresponds to the general concept of neopatrimonialism, as defined by $\mathrm{S}$. Eisenstadt [2] (in the classical "normative" institutions of public administration, the situation is reversed: the core is formal, and the periphery is informal);

-corresponds to the redistributive nature of the social coordination basic institutions in Russia (primarily in the economic, political and ideological spheres) [4];

-corresponds to the socio-cultural characteristics of the Russian "institutional matrix", which determine the possibilities and limitations of public administration institutional transformations, rebuilding "for themselves" the models borrowed from developed countries;

•undergoes reinterpretation in the context of Russia's institutional development [5] according to the formula "mobilization system stagnation - neopatrimonialism - renewed mobilization system”, becoming a value-neutral model - and not one that is viewed as a model of "unworthy governance” (V. Gel'man [3]) which is to be overcome.

2. The introduction of "redistributive neopatrimonialism” as a public administration model reflecting Russian specifics makes it possible to improve the "coordinate system" defined by the three basic models of public administration mentioned above [20]:

-this "coordinate system" receives a second dimension to describe spiral movements (reforms and counter-reforms);

-this second dimension of the "coordinate system" should be socio-cultural, since the politicaleconomic interpretation of neopatrimonialism, 
based on the distinction between extractive and inclusive institutions (according to D. Acemoglu and J.A. Robinson [21]), turns out to be clearly simplified, bringing together all the motives of the participants an informal core to rent extraction and prestigious consumption [22; 23; 11];

-we are moving away from the idea of "catch-up modernization" as a repetition of the developed countries' path.

The proposed alternative is "redistributive neopatrimonialism," which:

-is a systemic model based on a system-institutional approach that takes into account all the main aspects of statehood institutions (economic, political, legal, socio-cultural, etc.);

-examines the reproduction, development, and stability of the Russian statehood in the context of the encompassing system "economic reproduction - political regime - public administration";

-is a value-neutral model and allows considering such characteristics of Russian statehood as sovereignty and "imperialness", the ability to launch mechanisms of political-economic mobilization;

-is open to the experience of different countries and the launch of effective mechanisms for the transfer of foreign experience, taking into account the socio-cultural characteristics of Russia.

3. What new does the hypothesis about the model of "redistributive neopatrimonialism" allow to bring into the characterization of the problem situation? And what are the opportunities it opens up?

First, this hypothesis sets up the analyst to "look at the root" of the problems that were listed above. It is becoming obvious that superficial explanations like gaps in legislation or lack of money are clearly insufficient. And the popular thesis about "bad institutions" gets new depth by pointing to the role of the informal core.

Secondly, the risks of digitalization acquire an additional dimension within the framework of neopatrimonialism. After all, the typical reaction to the problems of public administration under political constraints is "technocratic". But if earlier the "strictness of Russian laws" was at least "compensated by the nonbinding nature of their implementation", then as a result of digitalization we risk facing the fact that this saving informal component of Russian institutions will be "cut off" and we will find ourselves in a situation of "digital idiocy”. A similar situation was brilliantly played in the famous film by Georgy Danelia: "The aunt was removed - the counting machine was installed.” The relevance of this risk for Russia is associated with the neopatrimonial nature of the public administration current model, in which the informal core of governance institutions is significant.

Third, in the context of neopatrimonialism, digitalization not only increases risks but also creates additional opportunities. This happens in the logic of "turning disadvantages into advantages":

-creation of flexible digital platforms using the potential of neopatrimonial institutions selfcorrection based on their informal component, improvement of inter-level and interdepartmental feedback system;

-a new system of strategic planning and politicaleconomic mobilization based on advanced simulation and scenario modelling (while the informal core makes it possible to move away from rigid Soviet-style directive planning schemes and act flexibly);

•creation of "digital communities", improving the quality of public services and public participation, using the potential of network interactions based on the informal mechanisms of neopatrimonial institutions.

Fourth, the research hypothesis, based on the proposed balanced model of institutions, is that the balance of the formal and informal components of public administration institutions (or "skew" in one direction or another) is largely determined by the context of the encompassing systems: the sphere of public life, which includes this institution, and the institutional order as a whole.

The value-neutral interpretation of neopatrimonialism as a control loop within the framework of statehood opens up a broader view of such problems as the role of the state in the economy, the ratio of power and property, the national model of democracy, etc. allowing to adequately highlight and reasonably use the successful experience of the BRICS countries and some APR countries (Japan, South Korea, Singapore, Malaysia, etc.). At the same time, a clear understanding of the system stability mechanism allows predicting the factors of its instability and reducing the risks of imbalance [20].

\section{The place of neopatrimonialism in the cycle of Russia's institutional development}

One of the key challenges that neopatrimonialism poses to the functioning of the modern Russian state is the situations it engenders when one is declared in the Constitution, another is written in the laws, and law enforcement is something else. To some extent, this is the usual legal-legislative-governance-social reality (M. Ratz and his colleagues introduced in this connection a special neologism "govern-power" [24, p. 43]), especially if you look at this phenomenon in terms of the difference between theory and practice. On the other hand, these situations point to another important feature of legal reality: the inevitable abstractness of laws and the gap between their formulas and real situations. In this regard, the same authors introduce the idea of a special type of thinking-activity - "norm control", designed to solve the problems arising at these junctions [25, pp. 180-184, 190-192]. But this issue has a third - political aspect, which opens up in the discussion of special, so- 
called "hybrid" regimes (E. Shul'man [26]), in which the difference in constitutions, laws, and law enforcement acts as a defining feature of the "policy of power".

In our opinion, the "rut effect" and the problem of the "Russian rut" is best described in terms of institutionalism. They also describe the situation when one is declared in the constitutions, another is written in the laws, and the law enforcement, in this case, is some kind of third. But in countries like Russia, this "usual legal-legislative-governance-social reality" has special characteristics. These characteristics are best captured by the institutional concept of "neopatrimonialism," implying that the institutions of power include a formal shell and an informal core.

Institutions of power (like any other institution) in Western countries also have formal and informal components. If we talk about laws, then the informal component is objectively necessary because the law, concerning a specific situation, due to its normative nature is either too abstract (that is, it allows arbitrary interpretation "at the discretion" of the law enforcement officer), or too casuistic (and then the situation needs to be informal "fit" under the law, and if it turns out to be outlawed, then, again, it will be settled informally "at the discretion" of the law enforcement officer).

But in Western countries, the informal component acts as a "spirit of the law" that does not directly conflict with its "letter", while in countries like Russia, it often turns the law into a "drawbar" that can be turned how the decision-maker wants. As a result, a double standard arises, which is friendly to our close circle and judges others according to the law. And the next logical step required to control the power over "outsiders" is "tightening the screws" when the law becomes such that it is impossible to enforce it literally. Hence the famous aphorism: "The severity of Russian laws is compensated by the non-binding nature of their implementation.” But it is compensated only for the time being since everyone is "hooked" in power - and when someone disagrees with the informal "rules of the game", they are immediately treated "according to the law".

Of course, the situation where law implementation is perverted for the sake of "rent-building" and "prestigious consumption" is an important special case of neopartrimonial power institutions. But in the general case, we should talk about the splitting of "normal" institutions into law enforcement megamachines and "secondary" institutions of informal governance, which set goals for law enforcement megamachines. These goals can be economic, but they also can be another. So, it can be a "political order", transmitted through "telephone law", or the interest of the bureaucracy selfpreservation. Or there may be quite noble goals of modernization or defense of the country from the aggressor. In other words, the real palette turns out to be much richer than Gel'man's.

How does the decision-making system work in neopatrimonial power institutions? This is an extremely difficult question in the study of public administration. It is extremely difficult to get close to the "decisionmaking system" at the state level in Russia, especially if we want to avoid psychologism. To do this, it is necessary to grasp the decision-making process as an element of the governance activities system, presenting the latter as a repetitive "governance cycle" having 4 phases [1]:

1) analysis and planning ("preparation" of the decision);

2) decision making;

3) implementation of the adopted decision;

4) control, evaluation, and correction.

Accordingly, even if we do not know anything about how the decision is made, we can consider this process as a black box in the "frame" of the other three elements of the cycle. At the same time, in terms of actors (participants), it is necessary to distinguish between three types of problem situations (or "problem contexts") [27]:

1) unitary (when it is possible to determine a single "decision-maker", and for a controlled system, the goal “descends" from above);

2) pluralist (when several free and equal participants are forced to coordinate goals among themselves);

3) coercive (when there are several participants, but instead of freedom, we have the ability of one of them to force the others to make favourable decisions at the expense of some prevailing resources, that is, the "rules of the game" are unequal, questioned or absent altogether).

Accordingly, we have three types of the ruling (Control \& Administration, Management, Governance), in which the decision-making processes are fundamentally different [28].

As noted above (2nd part of this paper), this typology of the ruling is projected onto public administration, giving rise to models of "rational bureaucracy", New Public Management (project-target) and New Governance (social-network), corresponding to the ideas of the "strong", "effective" and "inclusive" state. In the West, these three models (and three ideas), historically appearing in this sequence, do not cancel, but "layered" on top of each other. In Russia and similar mediumdeveloped "non-Western" countries, the implementation of each model and their combination has its own characteristics, which we consider in the framework of the concept of "redistributive neopatrimonialism."

The meaning of the term "redistributive" is to indicate the peculiarity of the powers separation system, which is that the three classical "branches" of power are not independent (as in the framework of the "checks and balances system" characterized Western countries) but receive their real powers from the supreme power [29]. Their formal powers prescribed in the Constitution may differ from their real ones - this is the manifestation of the supreme power role as the informal core of the public administration system. The supreme power itself in such cases follows not so much the "letter" as the "spirit" of the Constitution and laws, acting "from higher considerations," that is, on the basis of the value idea [20] as the informal ideal core of the neopatrimonial state.

Within the framework of the "redistributive neopatrimonialism" concept, the term "redistributive" characterizes not only the state administration and the political system, but also the national economy, which, 
according to its basic principle of organization and coordination, is not market, but distributive. Therefore, strictly speaking, it cannot even be called "economy" (if "economy" is understood as a market type of organization). Svetlana Kirdina uses the term "redistributive economy" [4], and Olga Bessonova uses the term "razdatok economy", which is understood as an economic system where non-market mechanisms play a dominant role, and market mechanisms play an auxiliary, compensatory role [30].

In 2019, Bessonova proposed a new "integralinstitutional" paradigm of the socio-economic development of mankind, within which the market and razdatok are considered as two universal and mutually necessary ways of coordination [5, p. 8].

Bessonova also introduces the concept of the Russian civilization matrix. Its reproduction is based on a razdatok institutional core (dominant institutions), while the market played a subordinate role of compensatory institutions. This allows us to substantiate the hypothesis that the current crisis of the Russian economy and political system is associated with the exhaustion of the quasi-market model that the Russian civilization matrix uses at the transformational phases of its historical evolution.

Bessonova's concept, for all her claims to complexity, is still focused on economics. If we focus on public administration, the "quasi-market" phase can be correlated with neopatrimonialism, which is characterized by the actions of representatives of the informal core, not in public, but in private and group interests, implemented within the framework of state capitalism. But, taking into account the previous trajectory of historical development, it can be assumed that at other phases (Bessonova proposes a cyclic model "perinatal phase - structured phase - phase of institutional exhaustion - transformational phase” [5, p. 17]), representatives of the informal core act primarily in public, not private or group interests.

It is no accident that Bessonova categorically objects to the use of the term "power-property" proposed by the orientalist L. Vasiliev [31] and insists that the basic institution of the distribution economy is public-official property. But at the same time, we observe how at the transformational phase, when the dominant and compensatory institutions of the distribution economy temporarily change places ("quasi-market"), what "in theory" should be public-official property is used in private and group interests, there is a merger of power and property, giving rise to "institutional corruption". In this sense, the term "supreme conditional ownership" used by Svetlana Kirdina in the conceptual framework of institutional matrices and redistribution economics [4] seems to be more accurate (the term "redistribution" is also more preferable for us than "razdatok").

The term "supreme conditional ownership" applies to all four the historical evolution cycle phases of the institutional/civilization matrix since it indicates the main feature: the dominant type of property in the $\mathrm{X}$ matrix states is property, which on behalf of the society is controlled by the supreme power and those persons or organizations that this supreme power "distributed" the corresponding competences (this is indicated by the word "conditional"). At the quasi-market phase, such property can be "distributed", for example, to "oligarchs" - but, as historical experience shows, those "oligarchs" who forget that property has been transferred to them conditionally and violate the terms of its use are ostracized and deprived of this property. It is important to note that formally (by law) this ownership is private, while this ownership is supreme conditional according to informal rules supported by the supreme power, that is, the real core of the neopatrimanal institution system.

Also, control over the most significant property is gradually returning to the state, which paves the way for the transition to the next phase of the cycle, in which only the property that is not needed by the state to serve society remains private. In other words, private property becomes one of the compensatory institutions, and the overall ratio of the dominant and compensatory institutions returns from the "inverted" position to the "normal" one. And if the cycle of Russia's institutional development "according to Bessonova" is reinterpreted in the context of focusing not on the economy, but the state, then the formula will be "mobilization system stagnation - neopatrimonialism - renewed mobilization system.” The mobilization system will correspond to the "perinatal" and "structured" phases of Bessonova's cycle, stagnation - to the phase of "institutional exhaustion", neopatrimonialism - to the "transformational" phase (when redistributive and market institutions "change places") and, finally, the renewed mobilization system will correspond to the transition to a new "round" of the historical cycle of socio-economic evolution.

\section{Instead of a conclusion: the institutional dilemma of our time}

The foundations of the dichotomous differences between the $\mathrm{X}$ - and $\mathrm{Y}$ - institutional matrices, as well as the market and razdatok methods of coordination, are clarified by turning to the Marxist theory of social reproduction. K. Marx represented the reproduction cycle of economic activity as a dynamic system of four elements: production, distribution, exchange, consumption: "Production, distribution, exchange and consumption thus form a proper syllogism; production represents the general, distribution and exchange the particular, and consumption the individual case which sums up the whole" [32]. Production and consumption are opposites that can be combined into a system only thanks to the mediating elements, which are systemforming. At the same time, both distribution and exchange are needed to ensure full-fledged economic activity.

In the Asiatic mode of production (Asiatische Produktionsweise) [33], distribution dominates, in the capitalist socio-economic formation - exchange, in the slave-owning and feudal ones they are combined. There is an exchange in the Asiatic mode of production, but it is strictly regulated by the distribution of trade rights and quotas. Under capitalism, exchange develops into a 
general form of market relations, but the distribution continues to exist within firms and corporations, as well as within families (households). But firms, corporations, and households are "inscribed" in the market system, and exchange relations are system-forming - just as in the Asiatic mode of production these are distribution relations. In this sense, distribution and exchange - like Yin and Yang - are in a dialectical relationship: one element "protrudes" and dominates, but the second does not disappear, it is present, as Hegel would say, "in sublated (aufgehoben) form."

If following $\mathrm{O}$. Bessonova, we consider (re)distribution and exchange as systemic principles of coordination, then it is reasonable to look at them from the point of view of the organization theory, within which it is customary to distinguish three types of relationships and corresponding structures:

1) "vertical" (the principle of hierarchy, or subordination/order);

2) "horizontal" (the principle of cooperation, or an equal contract);

3) "network" (this is the most universal principle of coordination since in the mathematical sense a network is a graph of an arbitrary shape, including both "vertical" and "horizontal" connections).

In economic life, networking can connect large companies that take advantage of corporate hierarchy and economies of scale, and small independent firms that build flexible contractual value chains. In social practice, network relations can connect authorities, acting according to the principles of hierarchy and subordination, with structures of civil society, acting on the principles of self-organization and freedom of association.

In the world, not only the redistributive (hierarchical, order-based, founded on "vertical" ties), but also the market (contractual, based on "horizontal" ties) organization of the economy is gradually being replaced by the network organization. Examples are the "sharing economy" based on the sharing of property (from cars to real estate in so-called "co-living”), as well as innovative clusters and ecosystems built on the principle of coopetition (combining the words cooperation and competition, which resembles the modern version of socialist competition).

Thus, a completely new level of what in Marxism was called "socialization of production" arises. Only this happens not for the routine labour of industrial society, based on which Marx's Capital was written, but for creative labour in a modern innovative economy (or "knowledge economy"), in which "human capital" becomes the main productive force. In this case, the alienation associated with capitalist ownership of private property is removed (knowledge and know-how are at the real disposal of workers, not capitalists). Accordingly, preconditions arise for the labour to cease to be sold.

To what has been said in this part of the paper, it should be added that the described socialization of production at a new technological level of productive forces in combination with the socialization of consumption processes in the "sharing economy" creates conditions for overcoming the main contradiction of capitalism - between the social form of production and the private form of appropriation. In a situation where the consumption process is socialized, it is logical to socialize the means of production. O. Bessonova calls it "solidarism" [5, p. 24-25]. This was possible before in the so-called "people's enterprises", but in the industrial era, such cases were rather the exception, and within the network organization there are prerequisites for this to become the rule.

Digitalization and the development of modern information technologies (in particular, blockchain technologies) create opportunities for building economic relations without intermediaries and speculators and political relations without corruption and with a minimum of bureaucracy. True, a number of very complex problems of organization and self-organization arise here, associated with the rules for regulating such relations, guaranteeing these rules, and resolving conflicts. In other words, the questions about how the previous functions of the legislative, executive, and judicial authorities will be implemented in the new society, that is, questions about the model of the system of institutions, are being actualized.

The scenario for the future development of neopatrimonialism depends on the path chosen by each particular country to solve the institutional dilemma of our time. Formally, there are three options:

1) a radical transformation of the economic, political, and ideological spheres for the implementation of the developed countries basic models, described in the 2nd part (it actually implies a change in the institutional matrix);

2) consolidation of the neopatrimonial system as a stable form of organization of the economy, politics, ideology, and public administration with the transformation of neopatrimonialism into a "new normality";

3) transition to an integral form of organization of the economy, politics, ideology, and public administration within the framework of the renewed mobilization system.

This paper was prepared as a part of the research work within the framework of the Government order for the RANEPA.

\section{References}

1. S.V. Bespalov, V.G. Maracha, Public Administration, 19, 4 (108), 25-31 (2017)

2. S.N. Eisenstadt, Traditional Patrimonialism and Modern Neopatrimonialism (Sage, Beverly Hills, 1973)

3. V.Ya. Gel'man, Political Foundations of 'Unworthy Governance' in Post-Soviet Eurasia: Outline for a Research Agenda (Preprint M-49/16) (Europ. Univ. in St.Petersburg Pub., 2016) [in Russia]

4. S.G. Kirdina, Institutional Matrices and the Development of Russia: an Introduction to $X-Y$ theory (Nestor-History, St. Petersburg, 2014) [in Russia] 
5. O.E. Bessonova, World of Russia, 28(1), 7-31 (2019) [in Russia]

6. M. Bevir, Governance: a Very Short Introduction (Oxford Univ. Press, 2012)

7. V.G. Maracha, T.S. Krasnikova, Regional economy. South of Russia, 7(1), 66-78 (2019) [in Russia]

8. V.G. Maracha, Modern information technologies and IT education, 4(4), 1003-1010 (2018) [in Russia]

9. M. Weber, The Theory of Social and Economic Organization (The Free Press, New York, 1947)

10. N. Robinson, The Political Origins of Russia's 'Culture Wars' (Department of Politics and Public Administration University of Limerick, 2014)

11. V.Ya. Gel'man, Modernization, Institutions and the 'Vicious Circle' of Post-Soviet Neopatrimonialism (Preprint M-41/15) (Europ. Univ. in St. Petersburg Pub., 2015) [in Russia]

12. D.C. North, J.J. Wallis, B.R. Weingast, Violence and Social Orders. A Conceptual Framework for Interpreting Recorded Human History (Cambridge Univ. Press, Cambridge, 2009)

13. J.-F. Bayart, S. Ellis, B. Hibou, The Criminalization of the State in Africa (James Currey, Oxford, 1999)

14. G. Erdmann, U. Engel, Neopatrimonialism Revisited - Beyond a Catch-All Concept (Working Paper 16) (GIGA Working Papers, Hamburg, 2006)

15. R. Sigman, S.I. Lindberg, Neopatrimonialism and Democracy: an Empirical Investigation of Africa's Political Regimes (Working Paper 56) (V-Dem Institute, Gothenburg, 2017)

16. M. Coppedge et al., V-Dem Comparisons and Contrasts with Other Measurement Projects, (Working Paper 45) (V-Dem Institute, Gothenburg, 2017)

17. M. Bratton, N. Van de Walle, Democratic Experiments in Africa: Regime Transitions in Comparative Perspective (Cambridge University Press, Cambridge, 1997)

18. A.D. Martin et al., Package MCMCpack (2020) https://mran.microsoft.com/snapshot/2017-081/web/packages/MCMCpack/MCMCpack.pdf

19. V.G. Maracha, S.V. Bespalov, E3S Web of Conferences, 217, 07029 (2020)

20. V.G. Maracha, S.V. Bespalov, Public Administration: Russia in Global Politics. Proceedings of the VII International Conference, 439-447 (2019) [in Russia]

21. D. Acemoglu, J.A. Robinson, Why Nations Fail: The Origins of Power, Prosperity and Poverty (Crown, New York, 2012)

22. V.Ya. Gel'man, Social Sciences and Contemporary World, 6, 34-44 (2015) [in Russia]

23. V.Ya. Gel'man, Social Sciences and Contemporary World, 1, 104-116 (2016) [in Russia]

24. M.V. Ratz, S.I. Kotel'nikov, Political Conceptology, 3, 29-68 (2015) [in Russia]

25. M.V. Ratz, S.I. Kotel'nikov, Political Conceptology, 1, 156-209 (2014) [in Russia]

26. E.M. Shul'man, Practical Political Science. Guide to Contact with Reality (AST, Moscow, 2018) [in Russia]
27. M. Jackson, Systems Thinking: Creative Holism for Managers (John Wiley \& Sons, Chichester, UK, 2003)

28. V.G. Maracha, Proceedings of the XIII All-Russian Meeting on Control Problems (VSPU-2019), 15581562 (Institute of Control Sciences RAS, Moscow, 2019) [in Russia]

29. N.A. Zaharov, The System of Russian State Power (Litera, Moscow, 2002) [in Russia]

30. O.E. Bessonova, Market and Distribution in the Russian Matrix: from Confrontation to Integration (ROSSPEN, Moscow, 2015) [in Russia]

31. L.S. Vasil'ev, In: Types of Social Relations in the East in the Middle Ages, 60-99 (Nauka, Moscow, 1982) [in Russia]

32. K. Marx, A Contribution to the Critique of Political Economy (Lawrence \& Wishart, 1971)

33. L. Krader, The Asiatic Mode of Production: Sources, Development and Critique in the Writings of Karl Marx (Van Gorcum, Assen, 1975) 